\title{
OEDIPUS-INSPIRED PINTOS: THE PLAGUE OF PRISONS IN TWO CHICANO TAKES ON THE PROTOTYPICAL MYTH OF CRISIS
}

\author{
Aikaterini Delikonstantinidou \\ National and Kapodistrian University of Athens, Greece
}

Abstract

This article discusses two revisions of the tragic myth of Oedipus in the light of recent studies on the American prison crisis. In 2010, Luis Alfaro's “Oedipus el Rey," a play that draws on Sophocles' Oedipus Tyrannus, addressed the national prison crisis which has encroached on barrio life with dreadful repercussions. One year later, Ernest Drucker employed the term "plague of prisons" to describe the phenomenon of mass incarceration in the US and shed light on its effects on poor communities of color, such as barrio communities. As if responding to Drucker's study and Alfaro's play, Law Chavez's "Señora de la Pinta," presented in 2012, gets its inspiration from the myth of Oedipus to dramatize US prison experience as a plague threatening the self and the barrio. The two plays are examined for what they reveal about the impact of the prison crisis on Chicano barrio life and Chicanidad.

Keywords: Oedipus Myth, Prison Crisis, Barrio, "Oedipus el Rey," "Señora de la Pinta."

PINTOS INSPIRADOS EN EDIPO:

LA PLAGA DE LAS PRISIONES EN DOS OBRAS CHICANAS

SOBRE EL MITO PROTOTÍPICO DE LA CRISIS

\section{RESUMEN}

Este artículo presenta dos revisiones del mito trágico de Edipo a la luz de los nuevos estudios sobre crisis carcelarias americanas. En 2010, la obra teatral de Luis Alfaro, "Oedipus el rey" (basada en el "Edipo tirano" de Sófocles) analiza la crisis nacional en las prisiones, que ha tenido terribles secuelas en la vida del barrio. Un año más tarde, Ernest Drucker acuñó el término "plaga de las prisiones" para describir el fenómeno de las encarcelaciones en masa en los EE. UU., explicando sus efectos en las comunidades pobres de color, como las del barrio. Con su dramatización de la experiencia carcelaria Americana como una amenaza a la identidad personal y colectiva del barrio, la obra de Law Chavez, "Señora de la Pinta" (2012) parece dar respuesta al estudio de Drucker y a la obra de Alfaro. El análisis de ambas piezas teatrales nos revelará el impacto de la crisis carcelaria en la vida cotidiana del barrio y en su "chicanidad".

Palabras clave: El mito de Edipo, crisis carcelaria, barrio, "Oedipus el Rey", "Señora de la Pinta”. 
The scapegoat ... becomes a judgment on that [social] order in its very being, embodying what it excludes, a sign of the humanity which it expels as so much poison. It is in this sense that it bears the seeds of revolutionary agency in its sheer passivity; for anything still active and engaged, however dissidently, would still be complicit with the polis, speaking its language and thus unable to put it into question as a whole. Only the silence of the scapegoat will do this.

-Terry Eagleton, Sweet Violence: The Idea of the Tragic, 279.

\section{PROLEGOMENA}

Prison riots were neither unheard of nor uncommon in the US before the 1980s. The prison riots of the early 1950 s and early 1970 s set regrettable precedents. However, they received scant interpretations as to their immediate and underlying causes and effects, and they prompted even less preemptive responses by national super/infrastructures. According to retrospective studies, the blatant lack of adequate understanding and responsible action vis-á-vis the uprisings and prison violence in general, along with a series of "shocks" to US economy, "a host of other social ills" (from racism and corruption to disorganization and poverty) and the concomitant demise "of ideological commitment to rehabilitation" (Colvin 1) caused the emergence of what is currently known as the country's "prison crisis." It is to the latter phenomenon that both Luis Alfaro's "Oedipus el Rey" (2010) and Law Chavez's "Señora de la Pinta" (2012) attend. Both plays draw on the tragic myth of Oedipus and, specifically, on the mythic episodes dramatized in Sophocles' Oedipus Tyrannus, "the prototypical model of the theatre of crisis" (Taylor 54), to frame their responses to the prison crisis, albeit focusing on different expressions of it.

Chavez's play thematizes the 1980 uprising at the New Mexico State Penitentiary in Santa Fe (PNM), the most violent in American history to date, which became a landmark event in the American prison crisis. The protagonist's participation in the riot forms the dark background of a modern Chicanx tragedy, which throws into sharp contrast the characters' struggles with honor, sexuality and loss. In the realm of recorded history, the thirty-six-hour bloodbath cost the lives of thirty-three prisoners and compromised the wellbeing of hundreds of tortured prisoners and officers. From the beginning of 2020, several local and national news outlets have been offering commemorations of the forty years since the horrific event, the most thought-provoking of which focus on its effects, still visible today. Brian Horton, for instance, writes of a lingering legacy of violence. Among other manifestations of that legacy, Horton mentions fragmentation among inmates, mutual distrust and thus derailed relationships between officers and inmates, as well as a profound "impact on the daily operations of the prison system"; a system which, in the post-riot years, grew exponentially bigger and, at the same time, far more contained. To these effects we should add the deep scars left by the 1980 penitentiary riot on New Mexico communities, especially in barrio communities and their Chicanx constituencies. To these effects Chavez, a native of New Mexico, points attention with his "Señora de la Pinta." 
The extent and depth of these effects comes as no surprise if we consider that most of New Mexico's population is Hispanic; that, at the time of the riot, the majority of the prison "guards and commanders were also Hispanic"; and that the Chicano prison population was high, as was Chicanos' power in prison society (Unseem and Kimball 89). In fact, although "African Americans were disproportionately represented at PNM relative to their population in the state and region," Chicano cliques had the greatest influence and thus "ran the joint" (Unseem and Kimball 89). Contrary to what one might expect, however, the Chicano prison population was disjointed and lacked intra-group solidarity or, at least, support. As Ernest Morris, then Deputy Warden, contends, Chicanos and other Hispanic inmates were subject to "the worst abuse and brutalization" (qtd. in Unseem and Kimball 89). This reality is painfully dramatized in Chavez's play, which also reveals that the fragmentation of the Chicano population inside the PNM mirrored and reduplicated a wider reality: serious friction and divisions became evident among Chicanxs even before the Raza Unida ideology and the Movimiento energy, which supported the Chicano nationalist project, but started losing ground gradually after the mid-1970s (Muñoz 123-152).

The increasing prevalence of gang subculture within Chicanx and other Latinx barrio communities, as well as the conflicting views held by these communities on gangs, especially after the subsidence of the radical activism of the 1970s, produced further friction and contributed to the development of factionalization within the Chicanx population (Michonski 25). Institutional, economic, demographic and social structural variables, all of them associated with class inequities and the rootedness of racism in the US, led to the formation of the gang subculture and, more noticeably, after the late-1970s, allowed gangs to spread throughout and gradually take control of the barrios (Acosta 5; Vigil, 41-42). The corrosion of community ties, for which the presence and workings of gangs (particularly their involvement in drug trafficking) is partially accountable, resulted in the destabilization of barrio communities. Yet, this unfortunate development had not only the side effect of fragmentation prevailing within the Chicano prison population; it also contributed to the country's prison crisis.

As scholar Ernest Drucker has argued, the destabilization of poor communities of color emerged, in the second half of the twentieth century, as one way "in which the plague of prisons has become self-sustaining" (47). He explains that high levels of arrest, imprisonment and recidivism concentrate in poor communities of color and are causally related to ethnoracial and class biases, discriminatory treatment, regimes of surveillance, as well as to the attendant social and economic insecurity of the said communities. The overrepresentation of these communities in the US prison system, in turn, damages "the social bonds that sustain life" and thus leads to increased crime, as punishment via incarceration "replaces the moral mechanisms of family and community" (47). According to Drucker, together with prison privatization, the industrial advantages derived from inmate labor, the multiplication of industries connected to and feeding back into the prison industry, and other super-structural interests vested in maintaining the prison-industrial complex, community destabilization resulted in incarceration 
taking on the contagious and self-perpetuating features of the plagues of previous centuries (47). ${ }^{1}$ And as the funding allocated for mass incarceration grows in reverse proportion to that allocated in public services that could keep down crime in at-risk communities, the "plague of prisons" only becomes more pervasive.

Here is where the focus of Alfaro's "Oedipus el Rey" lies. In Chicanx barrio communities all over the country, a vicious circle has been established since the late 1970s and is still at work in 2010, when Alfaro's play is presented as a call for action towards its breaking. The play propounds that marginalization, economic vulnerability and oppression sustain the gang subculture, which leads to further community destabilization and increases criminal activity, which, in turn, leads to high levels of incarceration and reinforces the presence of gangs in and out of prison, which then causes further marginalization/vulnerability/oppression and thus community destabilization, and so on. In other words, the ethnoracial and class targeting of mass incarceration re/creates the conditions of its own perpetuation, entrapping the country's more vulnerable youth in a mechanism of "social and political constitution," which establishes and preserves racist agendas, ethnic marginalization and class dominance (Whitt 185). In what follows, we examine how Alfaro's and Chavez's dramatic revisions of Oedipus' tragic myth respond to the noxious ways in which prison culture and barrio culture have come to interact and intersect in the past four decades. Our discussion of the two plays in the light of studies on the prison crisis will, hopefully, elucidate the repercussions of the crisis for Chicanx barrio communities and Chicanidad more generally, but also on the ways in which the resources of the community can be harnessed to create a front of resistance against the crisis.

\section{OEDIPUS' RECEPTION}

The presence of the Oedipus myth or, more accurately, Sophocles' version of the myth on the American stage dates to the nineteenth century. Yet, as Helen Foley documents, in the longest part of the myth's reception in the US, the eponymous hero was presented as "a descendant of the (Christianized and martyred) heroes of heroic melodrama" (6). It was in the 1970s that a more subtle "American identification with Oedipus' search for identity" emerged, "as well as an increasing willingness to confront Oedipus' role as a compelling yet potentially dangerous leader" (6). Along with the parallel outgrowth of new narrative and directorial

1 These include a relatively "well-defined starting point" in the early 1970 s as reported by Drucker: identifiable/identified causal agents, such as the ones noted above, as well as profiles of hosts; specific aspects of the environment that make the transmission possible, thus allowing the disease to spread; clear geographic foci; "subsequent evidence of the diffusion of new cases outward beyond" the initial geographical foci; as well as identifiable/identified "mechanisms of reproduction" and "sequences of cause and effect" conducive to the plague's perpetuation, which are contingent on the "three essential components of any epidemic: agent, host, environment" (50-67, 78-107). 
trends, new approaches and patterns developed to the myth's revision. In some cases, the myth gets structurally updated, as when a play modernizes the mythic elements yet follows the outlines of the myth, thus emerging as its "contemporary correlative"; in others, the myth undergoes what Miriam Chirico calls "catalytic conversion," when a play depends on the myth as impulse or catalyst to explore certain issues without, however, necessarily following its distinct outlines ("Divine Fire" 532). Among the varied patterns of revision that Chirico identifies, diegetical transposition, transfocalization, transvalorization, transmotivation, dramaturgical adoption and pragmatic transformation are six of the most commonly encountered on the US stage ("Hellenic Women" 18-20). These patterns of revision correspond to various degrees of inventiveness and experimentation with the mythic material "without being mutually exclusive" (20). The foregoing approaches and patterns, together with variously creative attempts at syncretizing Oedipus' myth with diverse US social identities, cultural traditions, even subcultural modes of expression and representation, allowed the myth to function as a potent vehicle for the exploration of a wide range of topical issues (Delikonstantinidou 2020). This is the case with "Señora de la Pinta" and "Oedipus el Rey," two instances of syncretic revisionary theatre, which serve to demonstrate that the myth of Oedipus belongs as much to the Chicanx world as to any other.

\section{3. "SEÑORA DE LA PINTA": PRISON EXPERIENCE AS THE OEDIPAL PLAGUE}

In his commentary on Chavez's play, which precedes an in-depth interview with the play's director Daniel Banks, Patrice Rankine grants that "the play is neither a one-to-one adaptation of the classical play [of Sophocles' Oedipus Tyrannus] nor an easy case of classical reception" (689). The application of Chirico's categorical classification with respect to patterns of dramatic mythic revision on Chavez's play shows the latter to be an instantiation of pragmatic transformation: a "type of revision [that] alters the mythic material so much that one-to-one correspondences between the original and the revision are no longer visible or important" (19). As commonly happens with the looser/less faithful cases of pragmatic transformation, in "Señora de la Pinta" the myth of Oedipus only "serves as a germ of an idea, a basic jumpingoff point, from which the playwright takes full license to create" (Chirico 19). Although Chavez has not necessarily relied on contemporary audiences' knowledge of the myth, the age-old tale does allow a "certain 'in' for the audience," to borrow Rankine's words (690). Chavez, then, has used the myth as a frame through which to look at and explore loyalty and honor, sexual identity and gender expression, and, importantly for our purposes, the traumatic experience of the 1980 prison riot in PNM and its implications for the Chicanx community of a Santa Fe barrio where the action is set.

Chavez makes sure he establishes early on that this play should be understood as an instance of mestizx theatrical mythmaking. "Señora de la Pinta" opens with a syncretic twist to the classical device of the chorus which, besides commenting 
on the action and foregrounding the presence of the community as in the classics, evokes ritualistic associations and points to a cross-cultural bond between the ancient Greek culture and the indigenous/Chicanx culture. The play's chorus consists of three lechuzas, human/wise speaking owls and "fabled characters in local lore" (Rankine and Banks 691), creatures which constitute symbols of knowledge, like owls did in ancient Greece. Yet, lechuzas take on extra roles in the local tradition and in the play: they will blind anyone who looks at them straight into the eyes, punishing both the ignorant and those who proud themselves of too much knowledge; they help heal those in need as the companions of barrio curanderas; and, quite suggestively in view of mother-son complications here, they enforce "the moral admonition to honor one's mother" (Miles 46). Thus, the conjoined issues of ignorance and the limits of knowledge are introduced from the play's very beginning and weave through it up until the end, when the play assumes its climactic significance.

The lechuzas, Yvonne's sympathetic neighbors named after the curanderas they serve-Isabelle, Angelina and Dolores-are the first to learn on TV about the carnage in the New Mexico Penitentiary (PNM), where Yvonne's youngest son, Tito, was serving time for selling barbitures. The three lechuzas are also the ones who shoulder the burden of breaking the news to his mother. After she learns of her son's hideous death during the riot (he was found raped and burned almost beyond recognition), Yvonne decides to honor his memory by remaining in ignorance of the ones responsible for his death. In her view, this decision will allow her to forgive his murderers "within reason" and thus let his soul rest in peace (Chavez 22). Contrary to Yvonne, who strives to leave behind knowledge of the riot's shocking specifics by holding tight onto the happy memories of Tito, the lechuzas seem both unable and unwilling to get past the traumatic event. One year later, and in their role as the embodiments of the spirit of the community and the voice of its values, beliefs and viewpoints, they keep returning to the issue of the riot. They repeatedly reflect on the conditions that led to it (including the inhuman living conditions of the PNM inmates and the power abuse suffered by them) (16-17), as well as on the costs the riot had in human lives and suffering, both immediate and long-term. Among the most insidious of these costs has been the growing distrust and aversion toward pintos; that is, ex-felons, like Gringo (or Vincente). This is no other than Yvonne's new partner, who was in prison at the same time as Tito and arrived at the barrio from PNM a while after the riot's suppression, having secured parole.

It is through Gringo's enigmatic background, shrouded in mystery for the most part of the play, and his search for the truth, which will ultimately destroy him, that Chavez joins the myth's plot with the plot of "Señora de la Pinta." Yet, Gringo's Oedipus-like figure does not search for the truth regarding his origins, but regarding the murderer of Yvonne's son and the circumstances of his death. Against Yvonne's wishes, and triggered by her daughter Jose (short for Josefina)the Creon-like figure of the play with whom he has an antagonistic relationship-, Gringo sets out to find the one responsible for Tito's violent end and avenge the victim and his family. His proclaimed goal is to honor her son's death and thus her and her loss, but equally important to him is to gain the acceptance of the barrio community that treats him with suspicion and as an outsider due to his pinto status. 
Barrio opinion is indeed divided over Gringo as the lechuzas serve to demonstrate; namely, although a small segment of the community sympathizes with Gringo for what he suffered while in prison and during the riot and for his wish to heal and "start a new life after going through that hell" (Chavez 16), others doubt that he is "a different man," one who has put his criminal ways and nightmarish experience of the riot "behind him" (18). Gringo is definitely not considered part of la familia, the barrio's sacred structural unit and principle, even when he is engaged to Yvonne. Therefore, any concerns as to his wellbeing are overshadowed by the most important concern of all, the wellbeing of the barrio (17). As Dolores revealingly comments, before she or anyone else knows what he did to get in prison or while in it, "Maybe it's not the riot that won't leave our minds, but having a killer like Gringo living here with us" (26). In this sense, he is seen as carrying the darkness of the prison experience with him like a plague, even before he is found guilty of anything. By means of Gringo's equivocal and rather problematic relation to the barrio and its people, the play underscores an important point: the rules by which the barrio abides are as binding and unforgiving as the prison rules. For all his macho confidence and good intentions, Gringo has been no more a free agent in the barrio than he was in prison. In both contexts, he is a largely overdetermined and peerless subject.

One of the most heart-rending strands of the play is that Gringo is aware of his outsidedness and this affects all his decisions, including the one that sets tragedy into motion: finding Tito's killer. Like a curse, the omnipotent force that shaped Oedipus' mythic biography throughout the myth's reception history, prejudice fuels his determination to prove himself to the barrio people while, at the same time, sealing the tragic destiny of the major players in the drama. As he says to Jose, when the latter confronts him about his past convictions, "Once you're a convicted felon you're automatically guilty for everything no matter what. The second time I was around the corner from an old lady that got robbed. They throw you in the pen for everything now, that's why it was so crowded" (Chavez 26). By thus dramatizing Gringo's position in the barrio world and his victimization by the omnipresent prison apparatus, the play's social critique evinces two related prongs. On the one hand, there is the ethnoracial disparity in imprisonment, which is correlated with a similar disparity in police stops and arrest, which, in turn, is correlated with overt or even unconscious ethnoracial bias, and the implementation of policies and practices evincing ethnoracially disparate assumptions and effects, such as law enforcement profiling (Behnke). On the other hand, there is the criminalization of individuals who have treaded on a path similar to Gringo; that is, Chicanos reduced to subcitizenship within the "hierarchies of membership, security, and agency" instituted by the prison apparatus "inside and outside prison walls," "what is sometimes called 'social death,"” as Matt S. Whitt remarks (184). Affected by the workings of the prison apparatus in the manner on which we reflected earlier, barrio culture colludes with it to filter Gringo's access "to the bases of social recognition and political agency" (Whitt 184). Indeed, barrio culture relegates him to a caste of "internal outsiders," against which the rest of the community, the population of "free" full citizens, is defined via negativa. Differentially interpellated in this way, pintos and non-pintos get ensnared in an "us versus them" opposition that, inevitably, 
exacerbates the community's corrosion. Substantial disparities, center/periphery relations and the skewed dynamics of persistent social hierarchies within Chicanidad come into prominence and belie nationalist narratives suffused by the (masculinist) ideology of carnalismo with its emphasis on unity and cohesion.

As Gringo starts probing into the specifics of Tito's life and imprisonment, we realize that Yvonne's son was similarly to Gringo stigmatized in the barrio community due to his unstable low-class life, as well as due to the unfortunate circumstances of his birth (as he and his sisters were born out of Christian wedlock and thus viewed as inferior to their peers). Like Gringo, Tito was relegated to the fringes of the community and left to his fate. It was a fate that soon came to take the form of law enforcement for him the same way it did for Gringo. Yet, the divisions within Chicanidad that the play unveils do not only concern Chicanos' pinto status, but also sexual and gender orientation. Tito, described as a "flamboyant" gay man by the parish's homophobic priest, suggestively named Father King, was treated as an embarrassing oddity in the barrio community (Chavez 12). Despite his excellent character, as revealed in the loving reminiscences of Yvonne, Jose and the lechuzas, Tito presented an aberration to the macho barrio culture. For his part, Gringo repeatedly voices the homophobic premises of macho barrio mentality by overemphasizing his masculinity, largely to salvage whatever acceptance and respect he can amidst the wary community. However, his fact-finding mission regarding Tito soon leads to a fatal discovery that discloses extra layers of meaning to his hypermacho declarations: Yvonne's son is no other than his lover in prison, called "Tattoo," due to a tattoo-like birthmark on his chest.

The recognition, catalyzed by the age-old birthmark device encountered in many a mythic career, including that of Oedipus, allows Gringo's masculinist behavior throughout the play to be interpreted in a different light, as an attempt to deflect his sexual frustration at having engaged in homoerotic practices while in prison. At the same time, by exposing the sexual hypocrisy of its protagonist, the play challenges the homophobic and manipulative strands of the modern cult of machismo and its pernicious effects on the politics and ethics of the Chicanx community, including the propagation of rape culture. ${ }^{2}$ Yet, it is not the secret of Gringo's "struggle [with] his sexuality inside la pinta," as Rankine put it (695), nor the fact that Tito/Tattoo looks a lot like his mother ${ }^{3}$-although the latter certainly adds pathos to the erotic complications of the drama- but Tito/Tattoo's death in Gringo's own hands that tunes the play to the tragic mode.

2 The first crime for which Gringo was convicted is viewed in a different light once his sexual complications become apparent. His unwilling participation in the rape of a teenage girl for fear that he would be rejected by his gang peers can be interpreted both as a mechanism for venting his frustration and as a traumatizing experience (Chavez 28). The play's treatment of Gringo's crime also comments on the presence of rape culture in the barrio world.

3 The title's “Señora" refers to Tito/Tattoo, endearingly called that by Tecato, an ex-con, who is confused by the boy's resemblance to his mother-confusion that exacerbates his mental distraction and becomes quite evident when he conflates mother and son during his revelations. 
The dramatic agent that sets the stage for tragedy here is not some otherworldly force as in the tragic myths of the Greeks, but the violence of the prison experience, during but also before the riot. Violence unravels in all its gruesomeness and goriness first, through Gringo's prison memories that the lechuzas conjure up (Chavez 55-60); then, through the quasi-mystical encounter between Gringo and Tattoo (70-74); and finally, through the semi-coherent revelations of a slightly unhinged ex-con named Tecato (85-89), who was in prison at the same time as Gringo and Tito. Tito's horrible death and Gringo's involvement in it are shown to belong among its multifarious implications. In love with Tattoo, Gringo had been protecting the young man during their serving time from sexual abuse by the other inmates, who were incited by Tattoo's conspicuous homosexuality. When the riot broke out, Gringo hid Tattoo to save him from the other prisoners, who would rape and torture him to death. Upon realizing that he would be unable to stave off the rowdy mob for much longer once they found their hiding place, he tried to grant him a painless and quick death by breaking his neck. He then left to save himself without realizing that his attempt had failed to kill him. It was eventually Tecato who unintentionally finished off Tattoo by putting his body in the dryer to prevent the other prisoners from violating it.

Any hope that Gringo has been harboring of making peace with his deed, his (arguably controversial) motives and the haunting prison experience collapses when the truth is out in the open. His future with Yvonne is destroyed when the latter takes her own life, devastated by the realization that she is in love with her child's lover and murderer (Chavez 95). Knowing how much it had cost her not to have been married in church (due to the fact that her husband had been married before) and to have been unable to offer Tito a Christian funeral (denied to him by Father King due to his homosexuality), Gringo takes the blame for Yvonne's death so that she can be honored the way she wanted. But he cannot look at himself anymore, nor can he return to prison having seen what he has seen. Thus, he asks the lechuzas, the ones' who blind the ignorant and the arrogant like himself, to punish him by digging out his eyes (96). Initially hesitant, they eventually grant his wish and write the coda to this tale of loss by musing on the anti-prison qualities of the heart, holding close but holding free those it loves, and thus keeping them alivein memory, if not in fact.

The play's success in eliciting a sense of catharsis is due, in large part, to the authentic and consistent humanness with which the main characters and the relationships among them have been animated. But it is also due to the authenticity of the connection on which the play has been grounded between the violence of Oedipus' story and the "brutal and devastating violence" of the prison experience, to use Banks locution (693). The play's director perceptively argues that "Señora de la Pinta" has capitalized on the connection that Chavez has discerned between the tragic myth of Oedipus and "what happened in his own backyard, in his community ... and the prison, ... two backyards" that are not just contiguous, but conjoined (693). The play has allowed the mythic material to speak resonantly to the present and create the context to which the playwright needed to direct attention. Ultimately, "Señora de la Pinta" manages to communicate to its audiences that the "plague 
of prison," as manifested in all its violence via the 1980 riot, has shaped Chicanx communities, and has affected the internal workings and constitutive relationships of Chicanidad. It may even be, as Banks argues, that the ethical and political statement of the play reaches further to show that: "This doesn't just happen in New Mexico. This didn't just happen with the prison riots here. This isn't a racialized local story reduced to a bunch of criminals, of New Mexican Hispanos. This is a time, ageold issue, problem, journey, situation. And we need to see ourselves as part of that world history ...” (193).

\section{4. "OEDIPUS EL REY”: RECIDIVISM AND THE PIPELINE AS THE OEDIPAL FATE}

The same imperative that Banks spells out, to explore the contact points between our present(s) and the age-old question of violence affecting world history, as well as between ourselves and others whom we rarely consider "our own" enough to care about, motivated Alfaro to create "Oedipus el Rey." The Oedipus myth, and Sophocles' Oedipus Tyrannus more particularly, served as inspiration and ultimately structured Alfaro's response to the "plague of prisons," the implications of which the playwright had experienced firsthand when working with young people caught in the cogwheels of the Californian penal system. The play constitutes, in Chirico's terminology, a "contemporary correlative" of the mythic episodes that Sophocles dramatized in his renowned tragedy ("Divine Fire" 532). It also evokes the revisionary pattern of diegetical transposition, insofar as specific analogies are revealed "between the earlier depiction of the myth and the latter-day revision," set in 2010s California ("Hellenic Women" 20). Both the analogies and the inevitable anachronisms that "Oedipus el Rey" involves underscore the similarity and also the dissonance "between classical antiquity and the contemporary moment and ignite a spark of recognition" (19); recognition not necessarily of the myth itself, but of the timeless and transcultural resonance of the question of violence and the ways in which violence (mis)shapes fate, faith and love.

Similarly to "Señora de la Pinta" and also to his other dramatic revisions of the myths of Electra ("Electricidad") and Medea ("Bruja" and "Mojada"), Alfaro's "Oedipus el Rey" grew out of a community need. In this case, it was the need to deal with the multifaceted problems of recidivism and the "cradle-to-prisonpipeline" as these affect US barrios and, more specifically, Chicanx youth of an at-risk background, whose lives are tied, in one way or another, to the gang subculture and its geopolitics. The two related phenomena, which have been shown to feed into the country's prison crisis (Wright Edelman 152), and their implications for Chinanx communities form the focus of the play. In fact, their combined stress and impact function in Alfaro's revision as "a stand-in for Fate," as reviewer Chris Jackson notes. This Oedipus' struggle to transcend his fate and rewrite his/story translates into a struggle to overcome his ethnic and class origins and determine his future beyond or, rather, against "the sordid realities of the prison system and the gang-infected barrioscape" (Jackson). At a time when more and more members 
of America's growing lower-class citizens of color are being "condemned at birth to fulfill an ugly, impoverished, criminalized destiny" (Adler), the story of Alfaro's Oedipus gains special poignancy.

Yet, as Chay Yew, the director of the play's Chicago production stresses in the program of the performance, besides dramatizing the predicament of many a young "homeboy," the play also served as "a call to action," but also, we may add, as action itself. Both the play's dramaturgy and its production history sought to direct audiences' attention to the need for assuming individual and communal responsibility vis-à-vis the phenomena of recidivism and the pipeline. Both sought to galvanize target communities into attempting interventions aimed at "a fundamental paradigm shift in child policy and practice" (Wright Edelman 152), and at remedying realities that spell tragedy for disadvantaged/at-risk young people like Oedipus. More than that though, "Oedipus el Rey" became itself such an intervention through several means: by inviting diverse audiences (other than a theatre-going elite) for the play's productions; by flanking the productions with such events as forums with guest panelists (community leaders, professionals working in fields and areas relevant to the play's focus, social scientists and other social agents), pre- and post-show conversations, online dialogue and blogging; by collaborating with the intervention organization of the Homeboy Industries, ${ }^{4}$ and by creating professional opportunities for Chicanx performers and other theatre professionals, but also for at-risk and gang-involved youth. In one sense then, it has been an intervention on the tracks of social theatre, since "Oedipus el Rey" combined myth-making and theatre-making with activism to explore together with its variegated audiences "the same questions faced by those in Ancient Greece about the limits of free will and how to best break free of the tragic ties that bind into a more hopeful, liberated future," as Kevin Moriarty grants in the Production Note for the Dallas Theatre Center production.

Both the syncretic interplay between the Greek source material and the Chicanx culture on which "Oedipus el Rey" rests, and the interpenetration of prison culture and barrio culture, around which it thematically revolves, are established from the play's beginning via the device of the chorus or coro. The coro here operates as an instrument for giving expression to the communal spirit that permeates the play, as in "Señora de la Pinta," but the character is double. Namely, it stands both for the barrio community in the greatest part of the play and for the protagonist's surrogate family of tough inmates in Kent County State Prison at the beginning and end of the play. In taking on this double group personality, the coro mediates between the two communities both literally, via its interaction with and in its choreographed stage presence amidst the audience, and symbolically, via representing alternately the

${ }^{4}$ Homeboy Industries is the name of an organization that serves endangered gang-involved youth with services and programs constructed to meet their practical and educational needs. The organization has grown to become "the largest gang intervention, rehabilitation and re-entry program in the world." See, https://homeboyindustries.org/. 
community of prisoners and the community of citizens (Delikonstantinidou 153). This is a mediatory role that becomes all the more poignant and effective given the participation of actual former prisoners and gang members in the play's productions and their inclusion as attendees in the audience. In a sort of theatrical sleight of hand, Alfaro creates a bridge between the two communities, thus facilitating each to reach out to the other across a long-upheld cultural divide. At the same time, in having the members of the coro gradually slipping into their roles as the main players of the drama, that is, Oedipus, Tiresias, Laius and Creon, but not Jocasta, the play introduces the conflation of inside (prison)/outside (prison), which lies at the heart of its overriding prison metaphor (Delikonstantinidou 166; Jenkins 180).

It is through the coro's polyphonic, metatheatrical reflections on the nature of storytelling and fate, strongly alluding to the reception history of Oedipus' myth, that we are introduced to this new Oedipus: the "destined / to be ... / Destined" protagonist of the story they decide to collaboratively re-create (Alfaro 11). Oedipus is a young homeboy who has spent most of his life shuffling between barrio streets and correctional institutions, believing that he has lost his mother in early childhood and been raised essentially within institutional walls by the man he knows to be his father, Tiresias, the now blind ex-gang member (11). As one after the other the coro members slip into their respective roles in Oedipus' story, the truth about his originsthe same truth that he will not discover until it is too late-is revealed via a number of flashbacks enacted on stage. These are essentially the episodes that lay out the backstory of the main events: the parricide prophecy that Laius (the East L.A. barrio/ gang "King" invested in territorial intergang warfare) receives by a healer, when his child is still unborn (22-23); the birth of the ill-fated child (25); his violent snatching out of his mother's arms, which leaves Jocasta devastated (26); his exposure as an infant (27-28); and Tiresias' (then Laius' henchman) noncompliance with Laius' order to murder the infant (28). Like many a child lost in the pipeline, Oedipus has led, since Tiresias saved him, the kind of life where dreaming of loving mothers, or dreaming at all, is dangerous. "It's better to have nothing in your night, but sleep," he admits. For people like him, the night is either "deaf" (33) or plagued by nightmares.

In corroboration for Oedipus' wariness of dreaming, it is in a dream that he learns about the parricide he is fated to commit by a parliament of wise owls (Alfaro 35-36). As in "Señora de la Pinta," the owls, rich with knowledge-related symbolism, assume supernatural qualities. Here, they take up the role of the Sophoclean oracle, which sets the hero inexorably on his tragic life path. Forces beyond the control of the world's Oedipuses set a self-fulfilling prophecy and/as tragedy into motion in this case too, albeit cast in a different mold. Shadowy, otherworldly forces conspire with the worldly forces of ethnoracial bias, systemic disparities of quality and access to material and social resources, the omnipresent prison apparatus, and the ganginf(l)ected barrio with its intracommunity divisions and conflicts give his life its distinct and "destined" shape. Despite Oedipus' quasi-blasphemous declarations against divine agents, borne of his youthful impiety and arrogance, the young man would never risk harming his beloved father. Thus, he makes up his mind to apply for parole and be released from prison to avert the fateful outcome (40). Tiresias, for his part, strives to prevent both kinds of forces from destroying his son by giving 
him specific guidelines as to his post-release steps and by making him promise he will not head to L.A. in pursuit of "a place, possibility," as Oedipus longs to do (44). But Oedipus' desire to "be something ... more ... el mero mero" (9-11) and his hunger for another future get the better of him. Soon after his release, he breaks his promise and thus, unwittingly, the hope for a different outcome to his story.

The gears of tragedy begin to spin relentlessly, grinding his future to the stuff from which cautionary tales are made of from the moment Oedipus heads to L.A. His encounter with his biological father in a literal and metaphorical "middle of the road" is another lacuna in the Sophoclean model of the myth (that is, besides the episodes that preceded the post-oracle events) that the play fills. The mythical episode is amplified and dramatized: Laius bursts into a fit of rage against the stranger who blocks the narrow one-way lane with his car. Oedipus quickly joins in the display of macho bravado, ultimately outmatching Laius' exaggerated, masculine histrionics (Alfaro 49). The game of machismo, manifesting in distinctly misguided-even downright ugly-ways in the gang context where both men have been socialized (Michonski 25), turns the road-rage exchange between them into a murderous "quien es mas macho" vignette. Laius recognizes that it is his own son who is punching him to death moments before he breaths his last breath. He even yells out to him, but his voice and the truth it contains do not register with Oedipus, who hits Laius "in the face repeatedly with an absolute savagery and lack of emotion. It's hard and quick, like in a prison yard" (Alfaro 50). The stage directions here reiterate the conflation of inside/outside and lay truth to Thomas Jenkins' claim that "[e]ven outside of the prison yard, Oedipus seals his fate as if inside a prison yard: there is no outside, outside" for him (180). Prison culture, macho gang culture and the perverted masculinist ethics of both push Oedipus beyond the point of no return.

By the time he reaches downtown L.A., Laius has been dead for days, but Oedipus is, in a very real sense and much like Chavez's Gringo, already socially dead: a pinto, stigmatized due to his impoverished and prison background, criminalized for life and reduced to subcitizenship. Like Gringo, and like many a disadvantaged and at-risk youth struggling with the reality of the bulging prison pipeline (Edelman 152), he is received by the barrio people as a man "scarred" since birth, bearing a social stigma that prohibits him from becoming fully integrated into society and for whom it is only a matter of time to get outlawed once again (Delikonstantinidou 164). Besides their self-serving edge, the suspicions and spiteful comments of Jocasta's brother, Creon, against Oedipus, when the latter invokes their former acquaintance at Juvenile Detention for a point of entry to barrio life, reflect the stance of the barrio community toward the young pinto (Alfaro 51-57). Creon's and the barrio gente's grievances against Oedipus become acuter as when he becomes Jocasta's lover and partner, especially as the barrio/gang "Queen" starts investing him with power and authority at the same time as she assigns him more responsibilities related to gang workings (94-97). From the moment the two announce that they are about to get married, the presence of the young usurper of the barrio "throne" becomes the source of a plague of rampant discontent at the new order that threatens to destabilize the barrio community. Jocasta's lifelong fears at the barrio's unforgiving stance toward any threat of disruption to its fragile normalcy thus gain more and more substance. 
In his attempt to thwart their plans, Creon embarks on a fact-finding mission regarding Oedipus' past, but also appeals to the authority of the community's healers, who traditionally sit at the "King's" side, collectively known as Esfinge-an equivalent of the mythical Sphinx. Oedipus must get their permission to marry the "Queen" and thus rule over the "kingdom." Having paid light heed to Jocasta's warning as to the barrio mentality and intent on winning over the gente and thus standing proudly by her side, Oedipus defies Esfinge's authority. He not only triumphs over it/them by answering their localized version of a well-known riddle, but, in a hubristic display of macho power, he humiliates the three healers by forcing them to eat the pages of the Bible they have offered him as a welcoming gift (Alfaro 109-110). However, his overpowering of the Esfinge/healers only serves as a prelude to his defeat. The marriage of Oedipus and Jocasta is literally built on the wreckage of his blasphemy: the entire event is enacted on the Bible-littered stage (Delikonstantinidou 173). Jocasta cherishes the moment and places the "King's chain" around Oedipus' neck in utter ignorance of what has passed at Oedipus' meeting with the healers (Alfaro 111). Only after the wedding is over, one of them approaches her and informs her of Oedipus' actions. Realizing what the confetti-like bits that are covering the floor really are, she is shaken. And before the shock of this realization has worn off, Creon enters with Tiresias and the two men proceed to devastating revelations as to Oedipus true identity.

As is the case with Sophocles' hero, this "Oedipus' simultaneous discovery of his identity and his crimes entails not only admission of guilt, but also consciousness that his attempt to thwart the prophecy has failed"; thus, the discovery entails the "burden of self-consciousness" that only adds to his suffering (Edmunds 45). In a resonant display of self-referential awareness, Oedipus speaks of himself as a subject of/to a larger destiny that he was never able to change, while simultaneously nodding to the pedagogical import of his story: "Am I the way the lesson looks? Am I?" (Alfaro 120), he asks Tiresias. The play's gripping climax culminates in Oedipus' blinding by Jocasta's own hands after his desperate pleas to that effect and her suicide with his small prison-made blade (123). At the same time that a coro member is leading blind Oedipus to Tiresias so that they can head back to prison, the barrio exacts its revenge on Creon in "the old school way," with "the stealthy sound of one silencer bullet being shot" (123). "Can no man be feliz / until he's six feet under?" the coro asks (127), now donning the "prison character" once again and reiterating the gnomic statement which Sophocles used for the coda of his Oedipus Tyrannus (16781684). The age-old question is to remain suspended, showing the existential distance between the ancient past and the present to be closer than one would expect. The sound of prison doors opening is heard and the play closes the moment the doors do too. Oedipus is back to prison and one wonders whether he ever truly left it.

"Do we lay down / and take the fate / this world has given us? / or / can we break esta cycle / and tell new stories?" (Alfaro 128). If the predicament of Alfaro's Oedipus mirrors that of thousands of young people in contemporary US, the coro's concluding intonations underline the community's responsibility for remedying the realities of injustice, discrimination and dispossession that determine the storylines of those lives. This idea has been put forward by the play's productions in every community they have addressed and engaged, along with the related 
notion that the tragedy they witness-the betrayal of efforts at self-determination by uncontrollable worldly forces-does not simply concern an isolated individual fallen victim to the prison plight and his immediate context. Rather, it is the tragedy of barrio, Chicanx and other communities of/in crisis all over the country, a tragedy that reverberates across the ages. In this sense, Alfaro's "Oedipus el Rey" is akin to Chavez's "Señora de la Pinta." However, the former has taken a step further in the attempt to intervene remedially to the conditions it dramatizes by accompanying the play's performances, as well as the ethical and political statements advanced by the dramaturgy, with strategies that fall the tracks of social theatre. The strategies on which we earlier commented have rendered "Oedipus el Rey" into even more than a public forum of storytelling and listening (Delikonstantinidou 178). Indeed, they transformed Alfaro's interdisciplinary theatre/project into a kind of itinerant social theatre workshop, which offered participants a multifaceted, socially remedial opportunity and urged them to further act upon it.

\section{EPILEGOMENA}

One discernible incentive behind "Oedipus el Rey" and "Señora de la Pinta" is the need to have audiences conceive of young men like Oedipus, Gringo, Tito, youth victimized from birth, as their children, their people. By establishing this connection, both works seek to galvanize audiences into civic action toward contributing to the dismantling of the pipeline and the reintegration of pintos into the social fabric. In line with official reports and studies, both works have served to make the point that the way out of the prison crisis, out of recidivism and the infamous pipeline, can be found from within the community. As long as the barrio culture works in tandem with the prison culture, the social ills that are brought forth and fostered by this symbiotic relationship will only lead to the proliferation of tragedies like Oedipus': of lives destroyed while struggling against the binds of a fate made inexorable by society's neglectful ignorance (Delikonstantinidou 177). Certainly, the imperative for structural responses to this crisis is dire. Still, no largescale changes are going to be effective at the structural level and in terms of lawand policy-making, unless people like the protagonists of the two plays are given better chances within the immediate community context in terms of acceptance and belonging, as well as of everyday strategies of survival, to be able to lead different lives than the ones dictated by a deplorable combination of unfavorable origins, systemic neglect and lifelong social exclusion. However, the development of a front of resistance to the "plague of prisons" using community resources is shown in both plays to involve concurrent efforts to remedy divisions within Chicanidad that have been proven conducive to it. Whether Chicanidad have managed to harvest the rethought and retooled post-movimiento energy to respond to this challenge in the past decade is the subject of another paper.

REVIEWS SENT TO AUTHOR: 10-4-2020; REVISED PAPER ACCEPTED FOR PUBLICATION: 1-7-2020 


\section{WORKS CITED}

Acosta, Frank de Jesús. The History of Barrios Unidos: Healing Community Violence, ed. A.J. Ramos. Arte Público Press, 2007.

Adler, Tony. "Luis Alfaro's American Tragedy: Victory Gardens's Chicano-Inflected 'Oedipus el Rey'." Chicago Reader 18/07/2012. https://www.chicagoreader.com/chicago/oedipus-el-reyat-victory-gardens-theater/Content?oid=6985908. Accessed 26 May 2020.

Alfaro, Luis. "Electricidad." 2003. Theatrical script.

Alfaro, Luis. "Mojada: A Medea in los Angeles." 2015. Theatrical script.

Alfaro, Luis. "Oedipus el Rey." 2012. Theatrical script.

Behnke, Alison Marie. Racial Profiling: Everyday Inequality. Twenty-First Century Books, 2017.

Chavez, Law. "Señora de la Pinta." 2010. Theatrical script.

Chirico, Miriam. "Review of Divine Fire: Eight Contemporary Plays Inspired by the Greeks.” Theatre Journal 59/3 (2007): 531-533. Project MUSE, doi: 10.1353/tj.2007.0135. 25 May 2020.

Chirico, Miriam. "Hellenic Women Revisited: The Aesthetics of Mythic Revision on the Plays of Karen Hartman, Sarah Ruhl and Caridad Svich." Dramatic Revisions of Myths, Fairy Tales and Legends: Essays on Recent Plays, ed. Verna A. Foster. McFarland and Company, 2012. 15-33.

Colvin, Mark. The Penitentiary in Crisis: From Accommodation to Riot in New Mexico. State U of New York P., 1992.

Delikonstantinidou, Aikaterini. Latinx Reception of Greek Tragic Myth: Healing and Radical Politics. Peter Lang, 2020.

Drucker, Ernest. Plague of Prisons: The Epidemiology of Mass Incarceration in America. The New Press, 2011.

Eagleton, Terry. Sweet Violence: The Idea of the Tragic. Blackwell Publishing, 2003.

Edmunds, Lowell. Oedipus. Routledge, 2006.

Foley, Helen P. Reimagining Greek Tragedy on the American Stage. U of California P, 2012.

Homeboy Industries. Nonprofit Organization Homeboy Industries, 2019, https://homeboyindustries. org/. Accessed 26 May 2020.

Horton, Brian. "Legacy of New Mexico Prison Riot Costs Still Linger Today." Las Cruces. Sun News. 1 Feb. 2020. https://eu.lcsun-news.com/story/news/2020/02/01/legacy-new-mexicoprison-riot-costs-still-linger-today/4633937002/. Accessed 23 May 2020.

Jackson, Chris. "Review: 'Oedipus el Rey' by Luis Alfaro.” The Column with John Garcia. 21 Jan. 2014. http://thecolumnonline.com/review/01-27-2014_OEDIPUS-EL-REY/. Accessed 26 May 2020.

Jenkins, Thomas E. Antiquity Now: The Classical World in the Contemporary American Imagination. Cambridge UP, 2015.

Michonski, Karin. “Chicano Gangs.” Encyclopedia of Gangs, ed. Louis Kontos \& David Brotherton. Greenwood Press, 2008. 24-27.

Moriarty, Kevin. Production Note for Luis Alfaro's “Oedipus el Rey” at the Dallas Theatre Center, Dallas, 2013. 
Muñoz, Carlos, Jr. Youth, Identity, Power: The Chicano Movement. 1989. Verso, 2007.

Rankine, Patrice, and Daniel Banks. "On Remixing the Classics and Directing Countee Cullen's Medea and Law Chavez's Señora de la Pinta." The Oxford Handbook of Greek Drama in the Americas, ed. Kathryn Bosher et al., Oxford UP, 2015. 683-698.

Sophocles. The Complete Sophocles, ed. Peter Burian \& Alan Shapiro. 2 vols. Oxford UP, 2011. Green Tragedies in New Translations.

TAYlor, Diana. Theatre of Crisis: Drama and Politics in Latin America. UP of Kentucky, 1991.

Useem, Bert, and Peter Kimball. States of Siege: US Prison Riots, 1971-1986. Oxford UP, 1991.

VIGIL, James Diego. Barrio Gangs: Street Life and Identity in Southern California. U of Texas P, 1988.

Whitт, Matt S. "Sovereignty, Community, and the Incarceration of Immigrants." Death and Other Penalties: Philosophy in a Time of Mass Incarceration, ed. Geoffrey Adelsberg et al., Fordham UP, 2015. 174-192.

Wright Edelman, Marian. Interview with Kevin Chappell. "From the Cradle to Prison: Violence Is Not Just Killing Our Kids, But Incarcerating Them Younger and Longer.” Ebony (July 2008): 151-153.

Yew, Chay. Program for Luis Alfaro's “Oedipus el Rey” at the Getty Villa Outdoor Theatre, Chicago, Playbill, 2010. 
